\title{
Effect of Exogenous Organic Matter Application on Soil and Plant Elemental Composition in Pot Experiments
}

\author{
Lubica Pospíšlová ${ }^{1}$, Magdaléna Habová ${ }^{1}$ Eva Doleželová ${ }^{1}$, Ida Drápelová ${ }^{2}$ and Veronika Renčiuková ${ }^{3}$ \\ 1. Department of Agrochemistry, Soil Science, Microbiology and Plant Nutrition, Faculty of Agricultural Sciences, Mendel \\ University in Brno, Zemedelska 1, Brno 613 00, Czech Republic \\ 2. Department of Pedology and Geology, Faculty of Forestry and Wood Technology, Mendel University in Brno, Zemedelska 3, Brno \\ 613 00, Czech Republic \\ 3. Research Institute of Agricultural Engineering, Drnovská 507, Praha 6161 01, Czech Republic
}

\begin{abstract}
Content of macro- and microelements in plant and soil was studied after biochar, compost, digestate, lignite, and lignohumate application. Pot experiments were carried out in Phytotron CLF Plant Master (Wertingen, Germany). As tested plant lettuce (Lactucasativa) was used. Elemental composition was determined by AAS and XRF spectroscopy. Macronutrients content (Ca, Mg, K, and P) was determined by Mehlich III. Total content of carbon and nitrogen were determined by LECO TruSpec CN analyser. Results showed that different exogenous organic amendments statistically significantly influenced macro and micronutrients content in soil and plant. Satisfactory $\mathrm{C} / \mathrm{N}$ ratio for soil microorganisms was measured only after compost and digestate application. As concerns hazardous elements, no legislation limits were overstepped after application of the tested organic amendments. Bioavailability and their uptake by plants followed the order: $\mathrm{Cd}>\mathrm{Mn}>\mathrm{Zn}>\mathrm{Fe}$.
\end{abstract}

Key words: Haplic Cambisol, macro and micro elements, AAS, XRF spectroscopy.

\section{Introduction}

Today exogenous organic material is widely used in agriculture with the aim of improving soil quality, plant nutrients regime, and plant production. Most studies dealing with anthropogenic soil amendments are aimed at their safety, trace elements content, and bioavailability of toxic elements. Many various forms of microelements are presented in the soil environment and their impact on the soil and plant is primarily given by their speciation, mobility, bioavailability, and toxicity [1-3]. Plants represent a part of ecosystem through which toxic elements can get into the food chain. Plants may directly and indirectly increase elements mobility through the formation of preferential pathways along roots or by complexation processes. They can also retard metal

Corresponding author: L’ubica Pospíšilová, assoc. professor, research fields: quality of agricultural soils and soil organic matter chemistry. leaching through reducing deep seepage by water uptake, and by stimulation of microbial activity $[4,5]$.

Total content of micro and macro elements in different agricultural amendments should strictly follow legislation limits, because soil pollution continues to be a serious problem today. On the other hand, increased production of organic agricultural and urban wastes brings about an urgent need for finding a strategy for their application in agriculture as either soil amendments or fertilizers. Biochar is biomass that has been partially combusted (low temperature pyrolysis at $340-520{ }^{\circ} \mathrm{C}$ ). As a carbon rich material with a slow degradation rate it is often used as soil amendment in agriculture, and for soil remediation. It is considered to be more stable than soil humic substances and its application in depleted soils leads to increasing the carbon storage, sorption capacity and water storage $[6,7]$. The influence of charcoal application on soil productivity was reviewed by Spokas et al. [8]. They came to the conclusion that 
application of charcoal can influence the agronomic crop yield both positively and negatively but the inconsistent results could have been caused by different biochar types used in original studies. Compost is an organic fertilizer made of all kind of organic residues, waste biomass, and a portion of soil. After the controlled composting processes it is worthy organic material rich in nutrients and microelements [9]. Digestate represents a residue after anaerobic fermentation process in biogas stations. Its composition is mainly given by primary products and by digestion processes. It contains high amount of $\mathrm{N}-\mathrm{NH}_{4}{ }^{+}$usually. According to the definition it is closer to the mineral fertilizers $(\mathrm{C} / \mathrm{N}$ ratio is lower than 10:1), as quoted by Cigánek et al. [10]. Lignite represents a young brown coal, with a low degree of coalification. It has been used as a low range fuel for decades. Today is interesting its non-energetic exploitation in Nano-technology, land remediation, and in agriculture. Lignite can serve as a source of organic carbon and can positively influence not only transport of nutrients but also their bioavailability. Its application in agriculture is governed by the legislation setting limits of hazardous elements content. The interaction of metal cations and metal binding capacity of humic acids isolated from different coals, leonardite and soils was studied by Novák et al. [11] and Madronová et al. [12]. They came to the conclusion that the highest metal binding capacity was in soil HA, followed by lignite HA. Lignohumate is a waste from paper industry (= commercially a lignin sulphate product), rich in humic substances and micronutrients. Havel et al. [13] studied lignohumates chemical composition using LDI TOF mass spectrometry. They came to the conclusion that lignohumates consist of low molecular weight fulvic acids and high molecular weight humic acids, similar to lignite humates. They have also the growth stimulation effect for a wide range of plants.

The aim of our work was to determine total content of macro and micronutrients in plants and soils after application of selected exogenous organic materials (biochar, compost, digestate, lignite, and lignohumte) in pot experiments. Furthermore we studied the effect of applied organic materials on $\mathrm{C} / \mathrm{N}$ ratio which directly influenced biological and chemical soil properties.

\section{Material and Methods}

Haplic Cambisol (locality Vatín, Czech Republic) was chosen for pot experiments, because some field experiments with exogenous organic matter application taken place on the same soil type as well. The locality is a part of School Enterprise, Faculty of AgriSciences, Mendel University in Brno [14]. Pot experiments were carried out in Phytotron CLF PlantMaster (Wertingen, Germany). Regime is $20{ }^{\circ} \mathrm{C}$ for day, $18{ }^{\circ} \mathrm{C}$ for night, air moisture $65 \%$, duration of sunshine is $12 \mathrm{~h}$, and intensity of lighting is $300 \mu \mathrm{M}$ $\mathrm{m}^{-1} \mathrm{~s}^{-1}$. Five different exogenic organic materials were applied (biochar, compost, digestate, lignite, and lignohumate) into Haplic Cambisol which itself serve as a control substrate. Experiments were done triplicate and the ratio of amendments and soil was 1:20, except lignohumate, where the ratio was 1:40 to avoid high soil salinity. As tested plant we used lettuce (Lactucasativa).

Basic characteristics of amendments and Haplic Cambisolare were shown in Table 1 and 2. Limits of toxic elements content and hygienic parameters in applied amendments were not overstepped and followed the legislation settings Act No 13/1994, 341/2008, and ČSN 465735 for agricultural lands. Biochar was obtained from the local producer (Pharmix Company, Czech Republic). Compost was prepared from grass, leafs and a portion of soil in the Research Institute of Agricultural Techniques in Prague. Digestate was obtained reached from a private biogas station in NovéMěstonaMoravě (Czech Republic). South Moravian lignite was obtained from the mine Mikulčice (Wien Basin, Czech Republic). Lignohumates were obtained from the private producer (Amagro Company, Czech Republic). After preparing the mixture of soil 
Table 1 Basic characteristic of studied exogenous organic amendments.

\begin{tabular}{lllllll}
\hline & Biochar & Digestate & Compost & Lignite & Lignohumate & Haplic Cambisol \\
\hline Dry weight (\%) & ND & 7.50 & 25.00 & ND & 50.00 & ND \\
$\mathrm{C}_{\text {total }}(\%)$ & 48.62 & 2.20 & 12.00 & 44.90 & 38.50 & 1.43 \\
$\mathrm{~N}_{\text {total }}(\%)$ & 1.72 & 0.44 & 1.20 & 0.55 & 0.40 & 0.20 \\
$\mathrm{C} / \mathrm{N}$ & 28.27 & 5.11 & 10.00 & 81.64 & 96.25 & 7.13 \\
$\mathrm{Ca}(\mathrm{mg} / \mathrm{kg})$ & $\mathrm{TA}$ & 1.30 & 28.10 & 2.76 & 527.00 & 868.00 \\
$\mathrm{~K}(\mathrm{mg} / \mathrm{kg})$ & $\mathrm{TA}$ & 5.00 & 21.20 & 0.11 & 726.00 & 321.40 \\
$\mathrm{pH}$ & 8.50 & 7.84 & 7.50 & 7.04 & 9.45 & 5.10 \\
$\mathrm{Mg}(\mathrm{mg} / \mathrm{kg})$ & $\mathrm{TA}$ & 0.90 & $\mathrm{TA}$ & 0.43 & 127.10 & 208.60 \\
$\mathrm{P}(\mathrm{mg} / \mathrm{kg})$ & $\mathrm{TA}$ & 0.80 & 6.00 & $\mathrm{ND}$ & $\mathrm{TA}$ & 55.50 \\
\hline
\end{tabular}

(Where: $\mathrm{TOC}=$ total organic carbon, $\mathrm{ND}=$ not determined, $\mathrm{TA}=$ trace amount).

Table 2 Selected physical and chemical properties of Haplic Cambisol.

\begin{tabular}{lllllll}
\hline Soil type & $\mathrm{pH} / \mathrm{H}_{2} \mathrm{O}$ & $\mathrm{pH} / \mathrm{KCl}$ & $\mathrm{CEC}(\mathrm{mmol} / \mathrm{kg})$ & $\begin{array}{l}\text { Clay content } \\
(\%)\end{array}$ & $\begin{array}{l}\text { Conductivity } \\
(\mathrm{mS} / \mathrm{cm})\end{array}$ & $\begin{array}{l}\text { Carbonates } \\
(\%)\end{array}$ \\
\hline $1 *$ & 2 & 3 & 4 & 5 & 6 & 8 \\
Haplic Cambisol & 5.1 & 4.7 & 14.2 & 22 & 0.2 & 0 \\
\hline * (1) Soil type, (2) active soil reaction, (3) exchangeable soil reaction, (4) cation exchange capacity, (5) clay particles content, (6) \\
conductivity, (7) total carbon content, (8) carbonates.
\end{tabular}

and exogenous organic materials we followed in pot experiments the lettuce growing under controlled conditions. Plants were regularly watered and after approximately one month harvested (Fig. 1). At least, after harvesting elemental composition of soil and plants residues was determined. We used microwave decomposition after extraction in concentrated nitric acid (Ethos 1 microwave system, Milestone, Sorisole, Italy) by AAS spectrometer ContrAA 700 (Analytic Jena, Jena, Germany). Furthermore a portable XRF analyser ThermoScentigicNitron XL3 Goldd+ $(50 \mathrm{kV}$ and $200 \mu \mathrm{A}$ x-ray tube with an Aga node Large-area Silicon Drift Detector) was applied. Four filters provide an optimized excitation from potassium $(\mathrm{Z}=$ $19)$ to uranium $(Z=92)$. The XL3 analyser does not require any specific calibration. All analyses were performed in the Mining mode, which is based on the Fundamental Parameter (FP) algorithm. Samples were always fully cupped to ensure, infinitely thick sample condition. Every sample was analysed three times for $30 \mathrm{~s}$ per main, high and low filters and $120 \mathrm{~s}$ per light filter. Measured values were then averaged. Commonly used standard methods for chemical soil properties determination were used Pospíšilová and
Vlček [15]. Soil reaction and conductivity were measured using HANNA Combi pH \& EC. Available nutrients content was determined by Mehlich III method. Total carbon and nitrogen content were determined by elemental analyser LECOTruSpec CN (LECO Corporation Michigan). One way ANOVA analysis and Scheffé's multiple range test were used for statistical data processing.

\section{Results and Discussion}

Haplic Cambisolis sandy loam textured, with acidity of $\mathrm{pH} 5.1$ and potential soil acidity of $\mathrm{pH} 4.7$, and middle range cation exchange capacity of about $142 \mathrm{mEq} \mathrm{kg}^{-1}$ (Table 2). Total carbon content is about $1.43 \%$, which means low humus content. Quality of humic substances is low, with prevalence of fulvic acids. Therefore organic amendments are necessary to apply for improving soil chemical properties and fertility. Detailed chemical and mineralogical composition of the studied soil was published by Pospíšilová et al. [16].

Results of the most important macronutrients content in soil after exogenous organic amendments application are shown in Fig. 2. Haplic Cambisol on 


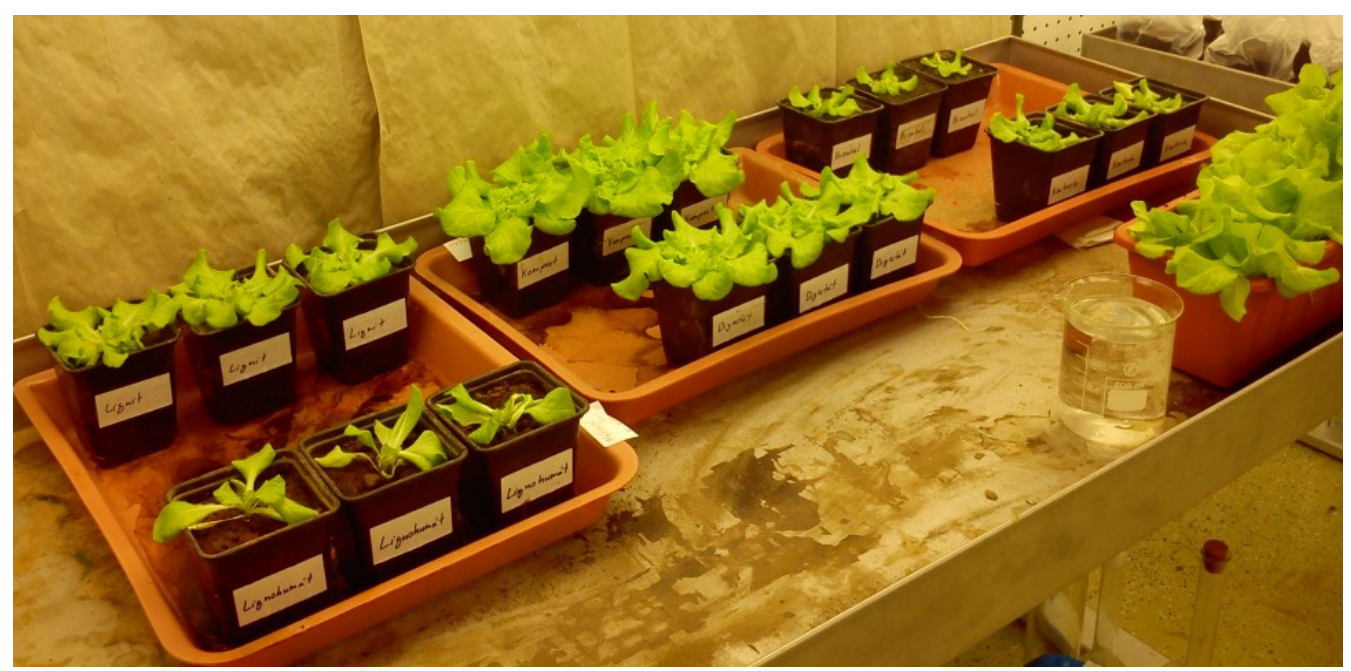

Fig. 1 Experimental vessel in air-conditioned box (Phytotron CLF Plant Master, Wertingen, Germany).

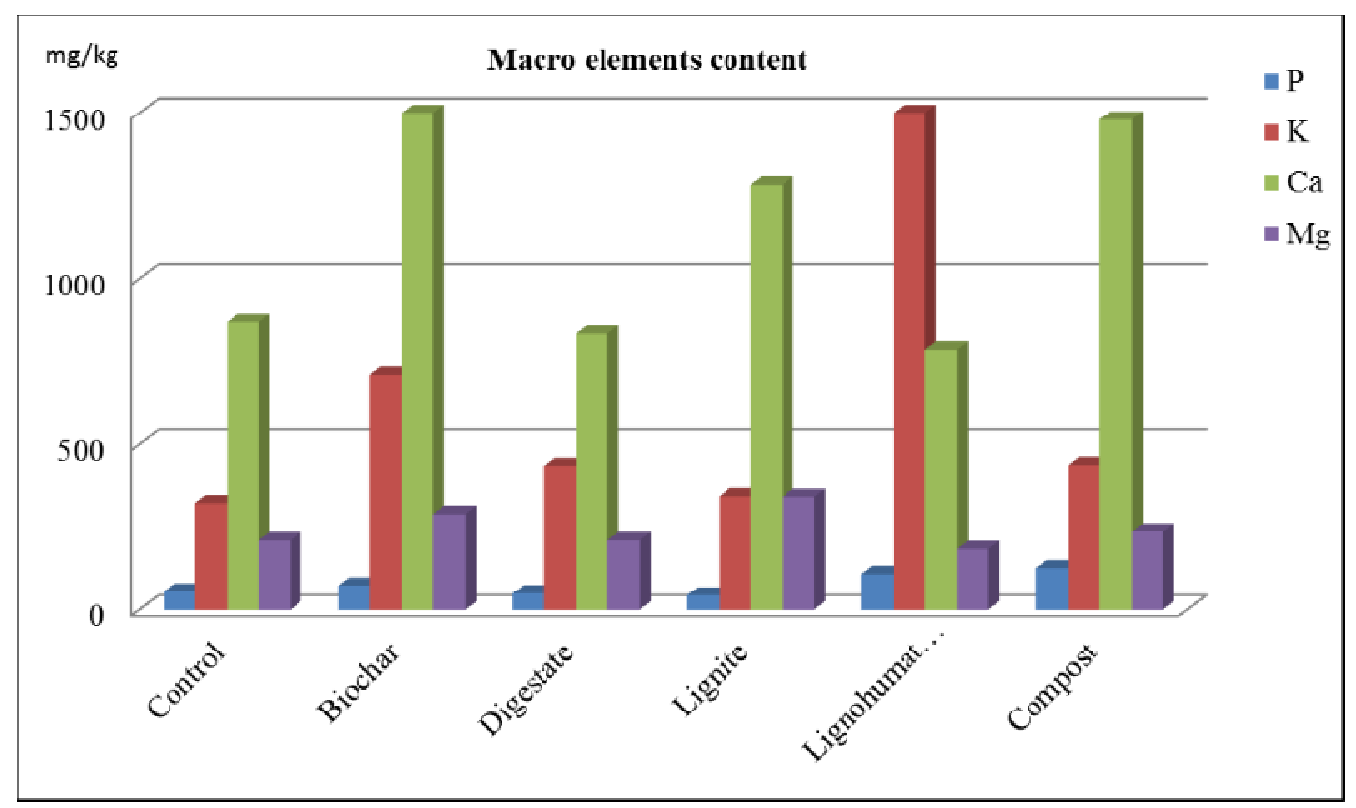

Fig. 2 Average macroelements content after exogenous organic amendments application.

control variant (without amendments) has satisfactory content of phosphorus $(55.5 \mathrm{mg} / \mathrm{kg})$, potassium $(321.4$ $\mathrm{mg} / \mathrm{kg}$ ), magnesium $(208.6 \mathrm{mg} / \mathrm{kg}$ ), and very low calcium content $(868 \mathrm{mg} / \mathrm{kg})$ — see Table 1 and Fig. 2. After compost, biochar, and lignohumate application content of phosphorus increased ( $>73 \mathrm{mg} / \mathrm{kg}$ ). Decreasing of phosphorus (less than $50 \mathrm{mg} / \mathrm{kg}$ ) was obtained after lignite and digestate application. This could be explained by very low content of phosphorus in both mentioned amendments (trace amounts- see Table 1). Extremely high content of potassium was detected after allamendments application (> 341 $\mathrm{mg} / \mathrm{kg}$ ). Especially after lignohumate potassium salt application content of potassium was five times higher to compare with control. From this reason we were also forced to apply ten times lower concentration of lignohumate potassium salt (= to avoid soil salinity in pot experiment). Calcium content increased after biochar, lignite and compost application. Low amount of calcium was found after lignohumate and digestate application (Fig. 2). Content of magnesium was the highest after biochar, lignite, and compost application. Average values of magnesium varied from $208 \mathrm{mg} / \mathrm{kg}$ (control) to $339 \mathrm{mg} / \mathrm{kg}$ (lignite) (Fig. 2). Total 
nitrogen content in mineral soil reached $0.20 \%$. Ratio $\mathrm{C} / \mathrm{N}$ was less than 10:1, which means an optimal ratio for soil microorganisms. Optimal $\mathrm{C} / \mathrm{N}$ ratio was also found after digestate and compost application. On the other hand, very high $\mathrm{C} / \mathrm{N}$ ratio was measured after biochar, lignite, and lignohumate application-see Table 1.

Micronutrients content determined by AAS method in soil after finishing the pot experiments is given in Fig. 3. XRF spectroscopy was mainly used for detailed characterization of soil elemental composition and following elements were determined-Si, $\mathrm{Fe}, \mathrm{Al}$, K, Ca, Mg, Ti, S, Mn, P, Ba, Zr, Sr, Rb, Pb and As. We can conclude, that after exogenous organic amendments application no legislation limits for hazardous elements content in soils and plants were overstepped. Micronutrients content in soil after exogenous organic amendments application was significantly higher to compare with control. Similar situation was detected in plants residues (leaves and roots). Average content of $\mathrm{Fe}, \mathrm{Mn}, \mathrm{Zn}$, and $\mathrm{Cd}$ in soil and plant residues is shown in Figs. 4-7. High affinity of lettuce to cadmium uptake is well known and lettuce is often used in cadmium contamination studies [17, 18]. In our experiments cadmium content in lettuce was ten times higher than in the corresponding soil substrate (Fig. 7) and generally elements uptake by lettuce followed the order: $\mathrm{Cd}>$ $\mathrm{Mn}>\mathrm{Zn}>\mathrm{Fe}$. One way ANOVA analysis and Scheffé's multiple range test showed statistically significant differences in $\mathrm{Fe}, \mathrm{Mn}, \mathrm{Zn}$ and $\mathrm{Cd}$ content between studied variants and also between control and all studied variants with exogenous organic amendments (biochar, compost, digestate, lignite, and lignohumate) (Table 3). Evaluation of toxic elements accumulation in plants and soil is important from point of view increasing risk elements in the agricultural products and water contamination. Microelements contained in different types of exogenous organic amendments are much more available for plants than those from a parent rock.

\section{Conclusions}

Different exogenous organic amendments directly affected macro and micronutrients content in soil and plants during the pot experiment. Satisfactory $\mathrm{C} / \mathrm{N}$ ratio was found only after compost and digestate application. No legislation limits for the content of hazardous metal were overstepped and hazardous elements mobility and their uptake by plants followed the order: $\mathrm{Cd}>\mathrm{Mn}>\mathrm{Zn}>\mathrm{Fe}$. High affinity of lettuce to cadmium uptake was confirmed.

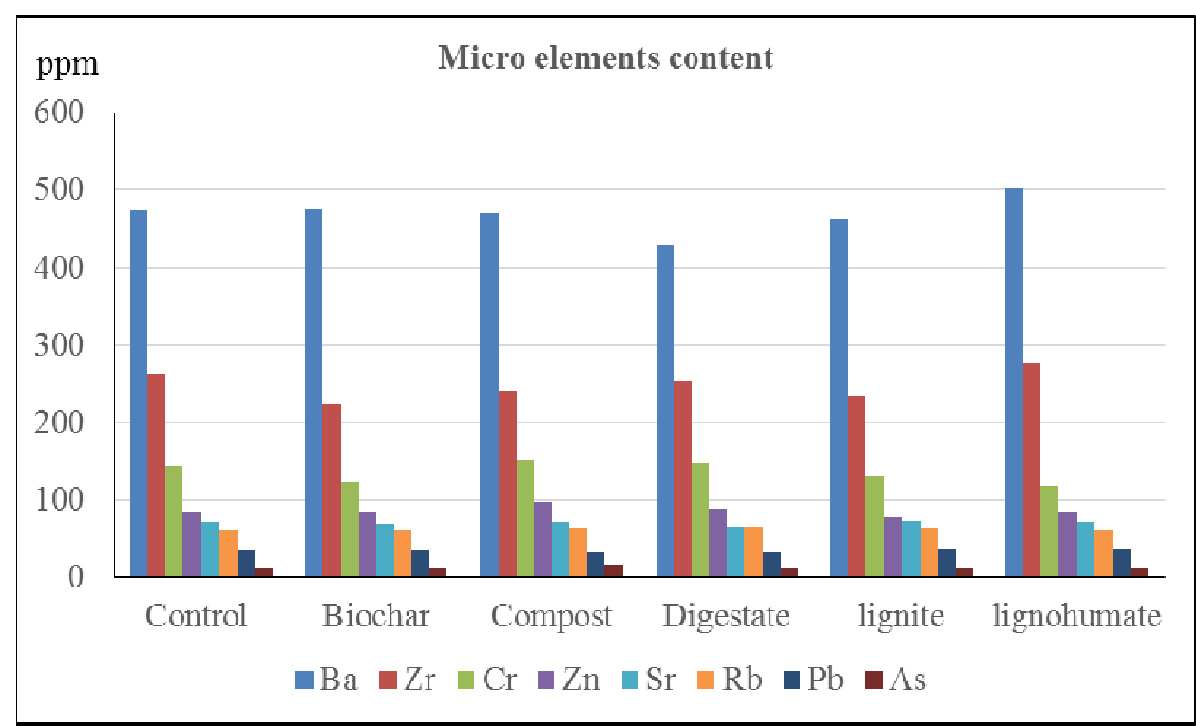

Fig. 3 Average microelements content after exogenous organic amendments application. 

Elemental Composition in Pot Experiments

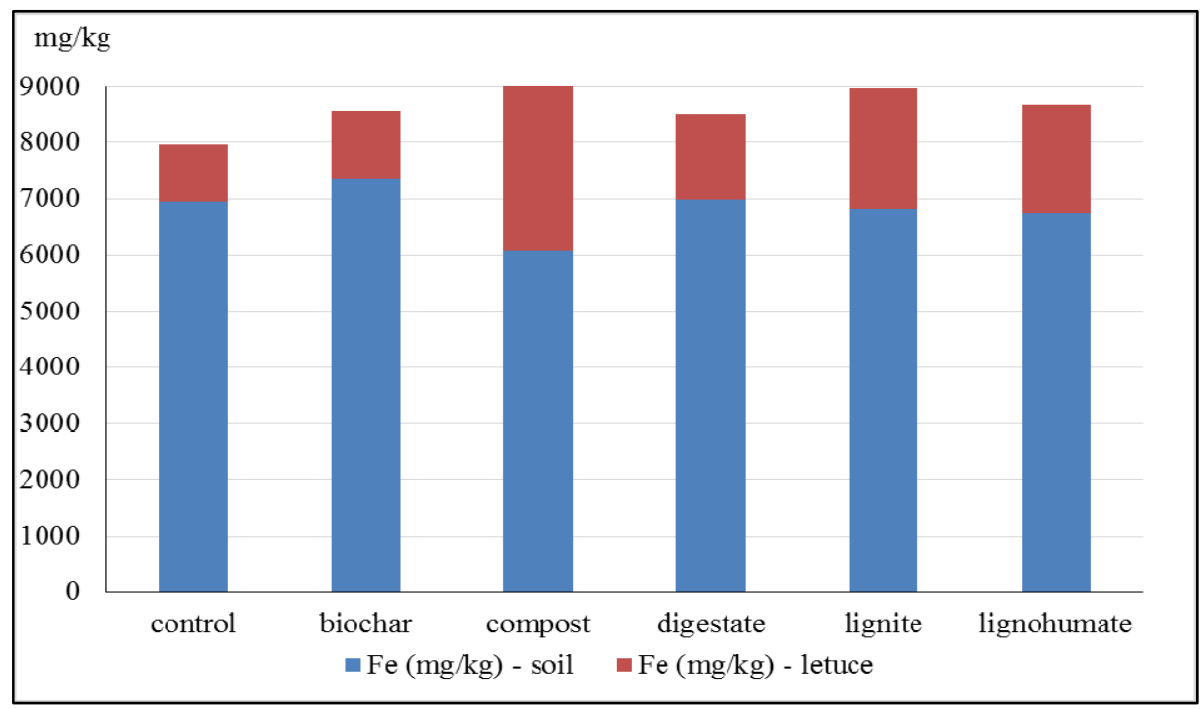

Fig. 4 Average content of $\mathrm{Fe}$ in soil and plant after exogenous organic amendments application.

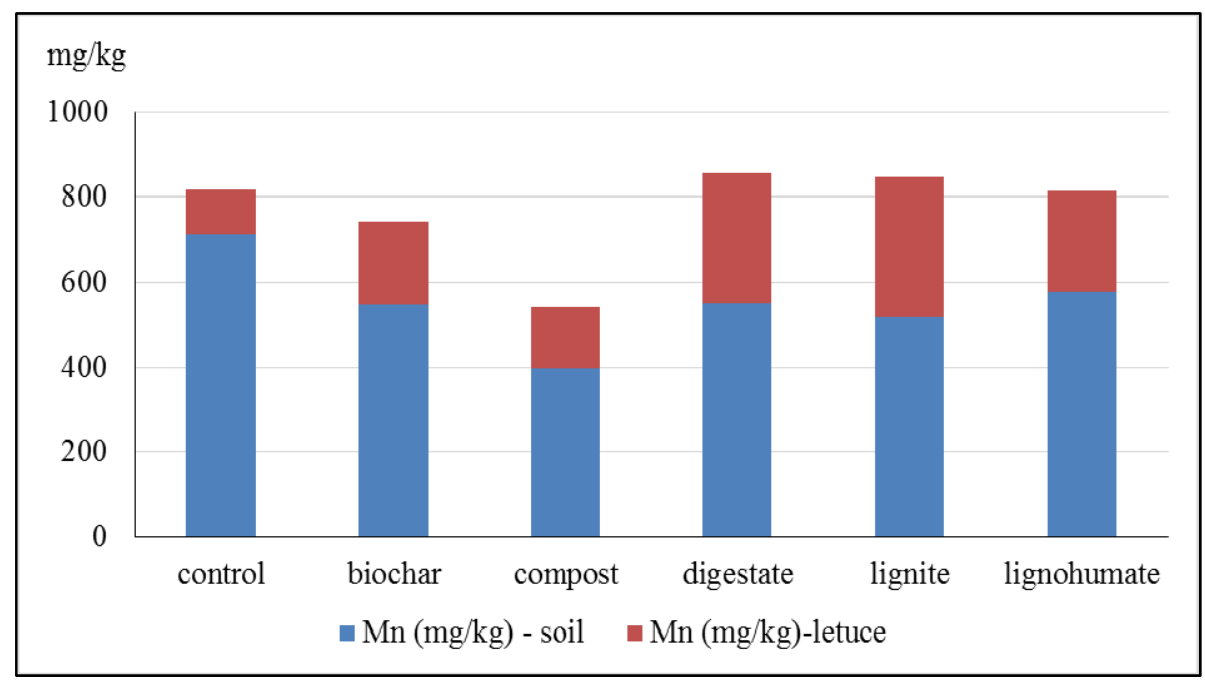

Fig. 5 Average content of $\mathrm{Mn}$ in soil and plant after exogenous organic amendments application.

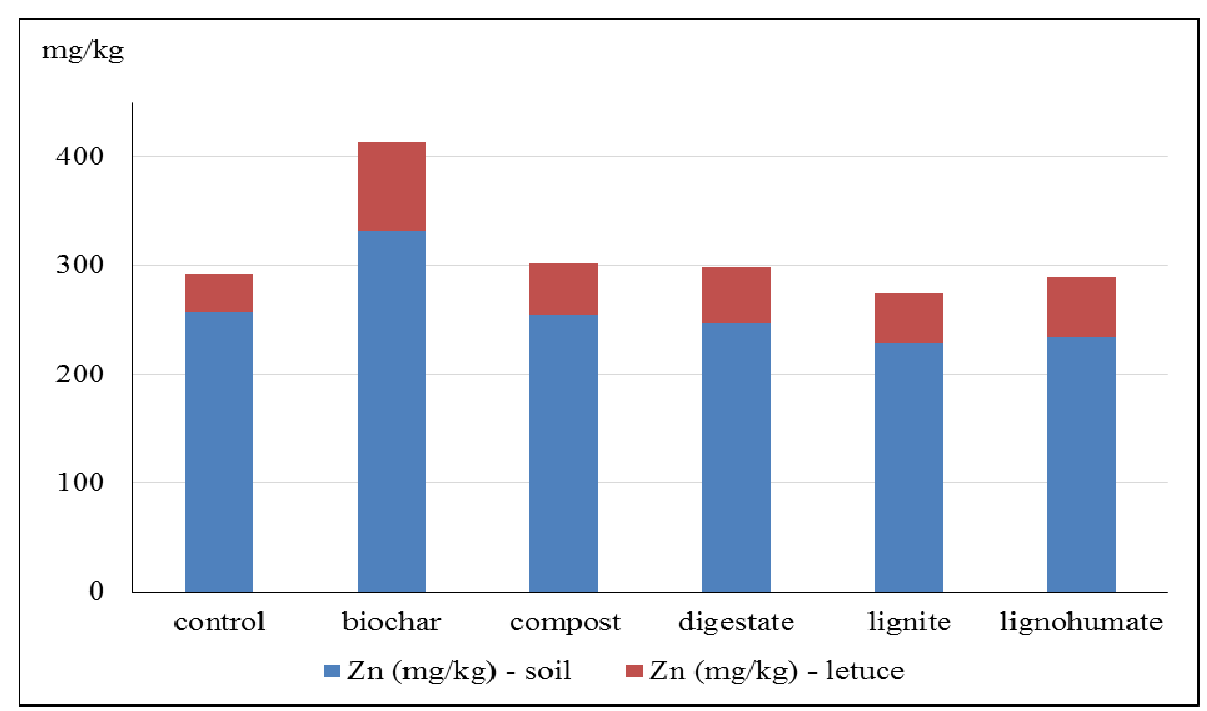

Fig. 6 Average content of $\mathrm{Zn}$ in soil and plant after exogenous organic amendments application. 


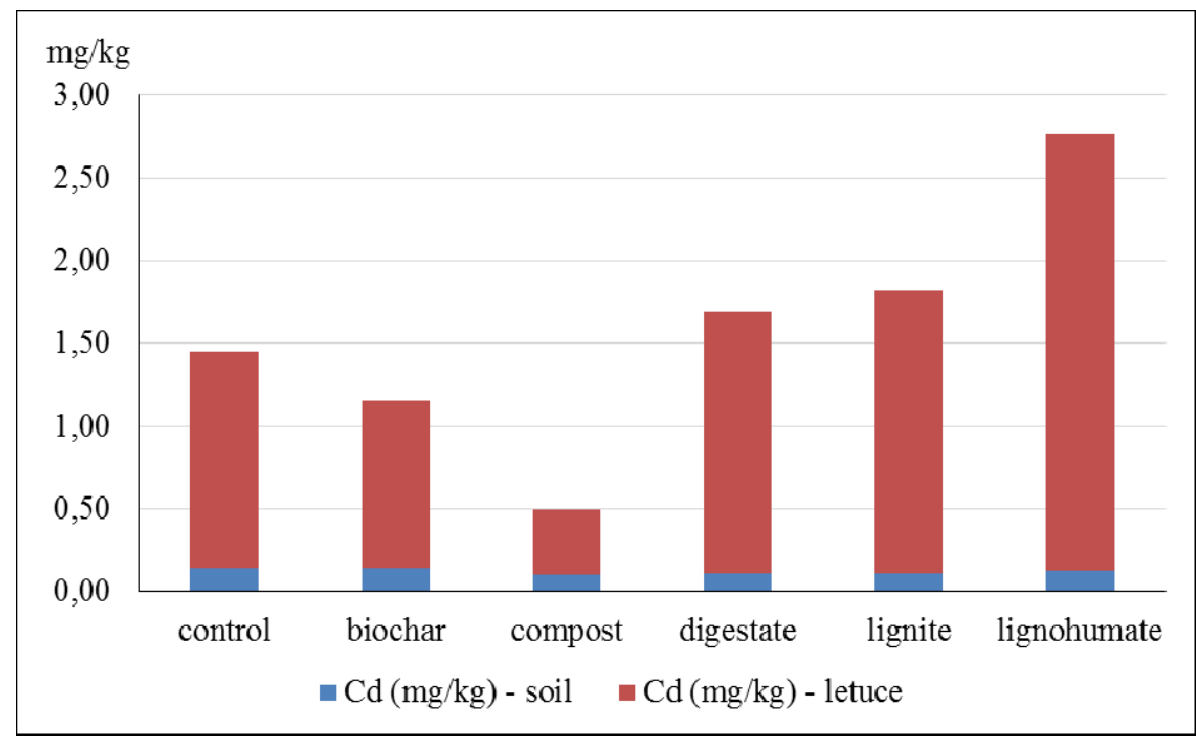

Fig. 7 Average content of $\mathrm{Cd}$ in soil and plant after exogenous organic amendments application.

Table 3 Statistically significant differences in elemental composition.

\begin{tabular}{|c|c|c|c|c|}
\hline \multicolumn{5}{|c|}{ Mean metal element contents $\left(\mathrm{mg} \mathrm{g}^{-1}\right)$ in dry biomass } \\
\hline \multicolumn{5}{|c|}{ Of the harvested lettuce plants } \\
\hline & Content & $\mathrm{kg}^{-1}$ & & \\
\hline Variant & $\mathrm{Fe}$ & $\mathrm{Mn}$ & $\mathrm{Zn}$ & $\mathrm{Cd}$ \\
\hline lignite & $2,631 \mathrm{a}$ & $337 \mathrm{a}$ & $45 \mathrm{a}$ & $1.576 \mathrm{ab}$ \\
\hline digestat & $1,458 \mathrm{a}$ & $305 \mathrm{a}$ & $49 \mathrm{ab}$ & $1.809 \mathrm{~b}$ \\
\hline compost & $2,581 \mathrm{a}$ & $138 \mathrm{a}$ & $42 \mathrm{a}$ & $0.461 \mathrm{a}$ \\
\hline lignohumate & $1,918 \mathrm{a}$ & $298 \mathrm{a}$ & $52 \mathrm{ab}$ & $2.058 \mathrm{~b}$ \\
\hline biochar & $1,121 \mathrm{a}$ & $185 \mathrm{a}$ & $92 \mathrm{~b}$ & $0.888 \mathrm{ab}$ \\
\hline control & $2,756 \mathrm{a}$ & $157 \mathrm{a}$ & $40 \mathrm{a}$ & $0.918 \mathrm{ab}$ \\
\hline
\end{tabular}

(Different letters within a single column indicate differences for the corresponding element (Scheffé's multiple range test, for $P<$ $0.05)$; a represents the lowest mean.

\section{Acknowledgments}

This study was supported by NAZV project Ministry of Agriculture Czech Republic No QJ 1210263 and by the Internal Grant of the Faculty of AgriSciences, Mendel University in Brno IGA IP 29/2015: Effect of soil conditioners on quantity and quality humic substances content in soil.

\section{References}

[1] Tessier, A., Cambel, P. G. C., and Bisson, M. 1979. "Sequential Extraction Procedure for the Speciation Trace Metals." Analytical Chemistry 51 (7): 844-51.

[2] Holm, P. E., Rootzen, H., Borggard, O. K., Moberg, J. P., and Christensen, T. H. 2003. "Correlation of Cadmium Distribution Coefficients to Soil Characteristics." $J$. Environ. Qual. 32: 138-45.
[3] Kabata-Pendias, A. 2004. "Soil-plant Transfer of Trace Elements-An Environmental Issue." Geoderma 122: 143-9.

[4] Fernandez, C., Monna, F., Labanowski, J., Loubet, M., and van Oort, F. 2008. "Anthropogenic Lead Distribution in Soils under Arable Land and Permanent Grassland Estimated by $\mathrm{Pb}$ Isotopic Composition, Environ." Pollut. 156: 1083-91.

[5] Sayyad, G., Afyuni, M., Mousavi, S. F., Abbaspour, K. C., Richards, B. K., and Schulin, R. 2010. "Transport of $\mathrm{Cd}, \mathrm{Cu}, \mathrm{Pb}$ and $\mathrm{Zn}$ in a Calcareous Soil under Wheat and Safflower Cultivation-A Column Study." Geoderma 154: 311-20.

[6] Lehman, J., and Joseph, S. 2009. Biocharsystem. In: Lehman C., Joseph S. eds., Biochar for Environmental Management: Science and Technology. Earthscan, London.

[7] de la Rosa, J. M., Paneque, M., Miller, A. Z., and Knicker, H. 2014. "Relating Physical and Chemical Properties of Four Different Biochar and Their Application Rate to 
Biomass Production of Loliumperenne on a Calcic Cambisol during a Pot Experiment of 79 Days." Science of the Total Environment 499: 175-84.

[8] Spokas, K. A., Cantrell, K. B., Novak, J. M., Archer, D. M., Ippolito, J. A., Collins, H. P., Boateng, A. A., Lima, I. M., Lamb, M. C., McAloon, A. J., Lentz, R. D., and Nichols, K. A. 2012. "Biochar: a Synthesis of Its Agronomic Impact beyond Carbon Sequestration." $J$. Environ Qual. 41: 973-89.

[9] Altman, V., et al. 2013. "Optimization of Water Regime in Landscape using Compost (Využitíkompostu pro optimalizaci VR v krajině, in Czech)." ZERA, Náměšt' n/Oslavou 101p. ISBN 978-80-87226-26-1.

[10] Cigánek, K., Lošák, T., Szostková, M., Zatloukalová, A., Pavlíková, D., Vítěz, T., Fryč, J., and Dostál, J. 2010. "Study of Efficiency of Digestate Application from Biogas Plant Station on to yield of Winter Rape and Winter Wheat and Changes of Selected Agrochemical Soil Properties (In Czech)." Agrochémia/Agrochemistry 14 (3): 16-21. ISSN 1335-2415.

[11] Novák, J., Kozler, J., Janoš, P., Čežíková, J., Tokarová, V., and Madronová, L. 2001. "Humic Acids from Coals of the North-Bohemnian Coal Field I." Preparation and Characterisation, Reactive \& Functional Polymers 47: 101-9.

[12] Madronova, L. 2011. "Humic Acids from Raw Materials of the Czech Republic.” Ed.: Nova Science Publishers, Inc., N. Y. 133p. ISBN 978-1-61668-965-0.

[13] Havel, J. 2010. "Laser Desorption and Ionization Mass Spectroscopy (LDI TOF MS) of the Lingo-humate Samples.” Research report, Masaryk University Brno 14p. (In Czech).

[14] Pospíšilová, L., and Tesařová, M. 2009. Organiccarbon inarablesoils (Organický uhlík obhospodařovaných půd, in Czech), Acta Folia II. UniversitatisAgriculturae et Silviculturae Mendelianae Brunensis, Brno 0-41.

[15] Pospíšilová, L., and Vlček, V. 2015. Chemické, biologické a fyzikální ukazatele kvality/zdraví půdy, Folia Universitatis Agriculturae et Silviculturae Mendeliannae Brunensis VIII, Brno 86p.

[16] Pospíšilová, L., Žigová, A., Št’astný, M., and Liptaj, T. 2012. "Humic Acids Quality of Cambisols Developed on Gneiss and Amfibolite." Acta Geodyn. Geomater. 9 (4): 503-10. ISSN: 1214-9705.

[17] Tang, X., Pang, Y., Ji, P., Gao, P., Nguyen, T. H., and Tong, Y. 2016. "Cadmium Uptake in above-ground Parts of Lettuce (Lactuca sativa L.)." Ecotoxicology and Environmental Safety 125: 102-6.

[18] Borůvka, L., Kozák, J., and Krištoufková, S. 1997. "Distribution of Cadmium, Leads, and Zinc in Plants Grown on Heavily Polluted Soils." Rostlinnávýroba 43 (6): 249-56. 